\title{
Relationship Between Ion Content in Seed and Spongy Coat of the Medicinal Halophyte Crithmum maritimum L. and Germination Capacity
}

\author{
Abdallah ATIA, Ahmed DEBEZ, Chedly ABDELLY, Abderrazak SMAOUI \\ Laboratoire d'Adaptation des Plantes aux Stress Abiotiques, Centre de Biotechnologies à la Technopole \\ de Borj Cedria,BP 901, Hammam-Lif, 2050,Tunisia; atbdllh@yahoo.fr
}

\begin{abstract}
Halophytes thrive in a wide range of habitats and climates, which may largely determine the seed mineral content, and hence influence both their germination capacity and their subsequent establishment. In order to assess this hypothesis, we performed a comparative study on three Tunisian proveniences of the perennial oilseed halophyte Crithmum maritimum $\mathrm{L}$. The ion $\left(\mathrm{Cl}^{-} \mathrm{K}^{+}\right.$, and $\left.\mathrm{Na}^{+}\right)$contents in seeds and fruits were determined and their likely relationship to germination capacity was addressed. Whether seeds were sown in distilled water or under moderate salt solution $(100 \mathrm{mM} \mathrm{NaCl})$ germination of the three proveniences was negatively correlated with the seed $\mathrm{K}^{+}, \mathrm{Na}^{+}$and $\mathrm{Cl}^{-}$content. The spongy coats (fruits) were found to accumulate much more $\mathrm{Na}^{+}$and $\mathrm{Cl}^{-}$than seeds (up to aprox. 8- and 11- fold, respectively for $\mathrm{Na}^{+}$and $\mathrm{Cl}^{-}$), indicating that efficient mechanisms may take place in order to protect seeds from the harmful accumulation of salt. In addition, the higher selectivity for $\mathrm{K}^{+} v$ s. $\mathrm{Na}^{+}$within seeds as compared to fruits seemed to be a determining factor in germination capacity of this species.
\end{abstract}

Keywords: Crithmum maritimum L., seed germination, salinity, $\mathrm{K}^{+} / \mathrm{Na}^{+}$selectivity ratio

\section{Introduction}

Variability of germination capacity under saline conditions is common among plant species, including halophytes. Marked differences in seed germination under increased salt concentrations were documented in Agropyron spp. (Dewy, 1960), Rumex cruspus (Caver and Harper, 1967), in three populations of Prospis fractal (Bazzaz, 1973), as well as in numerous proveniences of Atriplex halimus (Abbad et al., 2004). Depending on environmental conditions prevailing in their native habitats, halophyte seeds show great variability in their mineral contents, which may affect their germination capacity and their subsequent establishment. Seed nutrient content may also be species-dependent, as highlighted in the genus Acacia, (Rehman et al., 1996). In this way, the seed $\mathrm{Na}^{+}$accumulation during germination in saline medium was more pronounced in the non-halophytic xerophyte Haloxylon persicum (Chenopodiaceae) in comparison with two other halophytic Chenopodiaceae: Suaeda physophora and Haloxylon ammodendron (Song et al., 2005). Potassium $\left(\mathrm{K}^{+}\right)$ concentration was reported to be lower in the salt tolerant than in less tolerant species of Acacia (Rehman et al., 2000). However, $\mathrm{K}^{+}$accumulation is an indicator of salt tolerance during germination in the cultivated glycophyte Glycine max (Hosseini et al., 2002) and in the two halophytes Suaeda physophora and Haloxylon ammodendron (Song et al., 2005).

High salt accumulation in seeds may inhibit germination and/or affecting their viability (Song et al., 2005; Vicente et al., 2007). However, the precipitation period permit salt leakage and thereby enables germination of the viable seeds (Debez et al., 2004). Crithmum maritimum L. (Apiaceae) is a typical halophyte of rocky coasts ecosystems. In previous investigations, seed germination of C. maritimum L. was unaffected in the $0-100 \mathrm{mM} \mathrm{NaCl}$ range, but was severely reduced at higher salinity levels (Atia et al., 2006; 2009; Meot-Duros and Magné, 2008). This species shows substantial economical and medicinal potentials. Its seeds contain also significant amounts of oil, potentially edible due to its fatty acid composition, close to olive oil (Zarrouk et al., 2003). In order to ascertain whether the assumption that ions accumulated in seeds in their natural biotope may control the germination process, we compared in the present survey the germination capacity under saline and non-saline conditions of three Tunisian proveniences of the halophyte $C$. maritimum L. in relation to their ion $\left(\mathrm{Cl}^{-}, \mathrm{K}^{+}\right.$, and $\left.\mathrm{Na}^{+}\right)$contents in both the spongy coat (seed envelope) and the seeds.

\section{Materials and methods}

C. maritimum L. fruits were collected in the autumn 2001, from three geographic areas of North Tunisia: Tabarka (N-W), Kelibia (N-E) and Haouaria (N-E). The mesocarp of $C$. maritimum $\mathrm{L}$. forms an easy-removable spongy coat at the fruit maturation stage, whereas the endocarp and the secretory envelope remain firmly attached to the seed. Therefore, in this study the term seed refers to the seed plus the endocarp and the secretory envelope. Prior to the germination, the spongy-coat was removed and the seed disinfected for $5 \mathrm{~min}$ in a saturated calci- 
um hypochlorite solution (3.5\%). Seeds were then sown in $9 \mathrm{~cm}$ Petri dishes covered with a double layer of filter paper and moistened with either distilled water or a 100 $\mathrm{mM} \mathrm{NaCl}$ solution. The experiment was carried out in a growth chamber at the temperature of $18^{\circ} \mathrm{C}-23^{\circ} \mathrm{C}$ and 8 $\mathrm{h}-16 \mathrm{~h}$ dark-light phases. Light was produced by 5 fluorescent lamps (Type OS-RAM $40 \mathrm{~W}$, fluence of 35 photon $\left.\mu \mathrm{mol} \mathrm{m} \mathrm{m}^{-2} \mathrm{~s}^{-1}, 400-700 \mathrm{~nm}\right)$. Germinated seeds were counted each two days, in this report we define germination as the emergence of the radicle. The determined germination parameters were the final percentage germination and the germination velocity. The latter was calculated according to a modified Timson index (Khan and Ungar, 1984): $\Sigma G / \mathrm{T}$, where $\mathrm{G}$ stands for the germination percentage, calculated for each two-day interval and $\mathrm{T}$ represent the total germination time, here 36 days.

Furthermore, ion extraction in $0.5 \% \mathrm{HNO}_{3}, \mathrm{~K}^{+}$and $\mathrm{Na}^{+}$contents in seeds or in the spongy coat were determined by a Flame photometer, while $\mathrm{Cl}^{-}$was assayed using a Chloridometer. A Tukey's test was used to identify significant differences among means, using statistical software SPSS 10.0 for Windows.

\section{Results and discussion}

The principal goals of this investigation are to address the natural variability in seed and fruit ion contents of $C$. maritimum L. and to assess its influence on the plant germination capacity in the presence or or absence of salinity. Our results indicated that irrespective of the salt treatment, C. maritimum $\mathrm{L}$. germination was accession-dependent. In distilled water, the highest germination percentage was observed in Haouaria ( $\mathrm{H}, 90 \%)$, followed by Tabarka (T, 72\%) and Kelibia (K, 27.5\%) (Fig. 1a). Salt exposure reduced the percentage of germination in the three proveniences but to different extent: Haouaria showed only a slight reduction, whereas the detrimental effect of 100 $\mathrm{mM} \mathrm{NaCl}$ was much more pronounced in Tabarka and Kelibia accessions, 34\% and 8,3\% respectively. Changes in the germination velocity were similar to that of the ger-

Tab. 1. Salt $\left(\mathrm{Na}^{+}, \mathrm{Cl}^{-}\right.$and $\left.\mathrm{K}^{+}\right)$distribution between seeds and spongy coat of three proveniences of $C$. maritimum

\begin{tabular}{cccc}
\hline & $\mathrm{H}$ & $\mathrm{T}$ & $\mathrm{K}$ \\
\hline $\mathrm{Cl}$ fruit $/ \mathrm{Cl}$ Seeds & $9.4 \pm 2.14^{\mathrm{a}}$ & $10.9 \pm 2.9^{\mathrm{a}}$ & $6.02 \pm 0.21^{\mathrm{b}}$ \\
$\mathrm{Na}^{+}$fruit $/ \mathrm{Na}^{+}$Seeds & $8.35 \pm 2.6^{\mathrm{a}}$ & $8.39 \pm 1.16^{\mathrm{a}}$ & $5.82 \pm 1.54^{\mathrm{a}}$ \\
$\mathrm{K}^{+}$fruit $/ \mathrm{K}^{+}$Seeds & $1.61 \pm 0.05^{\mathrm{a}}$ & $1.69 \pm 0.16^{\mathrm{a}}$ & $1.03 \pm 0.16^{\mathrm{a}}$ \\
\hline
\end{tabular}

$\mathrm{K}=$ Klebia; $\mathrm{T}=$ Tabarka; $\mathrm{H}=$ Haourea. For each report means that have values that are marked with more letters are significtly different at $\mathrm{P}<0.05$

Tab. 2. Variation of $\mathrm{K}^{+} / \mathrm{Na}^{+}$ratio in seeds and spongy coat in three proveniences of $C$. maritimum

\begin{tabular}{lccc}
\hline & $\mathrm{H}$ & $\mathrm{T}$ & $\mathrm{K}$ \\
\hline $\mathrm{K}^{+} / \mathrm{Na}^{+}$ratio in seeds & $0.054 \pm 0.016^{\mathrm{a}}$ & $0.080 \pm 0.003^{\mathrm{a}}$ & $0.025 \pm 0.002^{\mathrm{b}}$ \\
$\mathrm{K}^{+} / \mathrm{Na}^{+}$ratio in spongy coat & $0.011 \pm 0.001^{\mathrm{b}}$ & $0.016 \pm 0.003^{\mathrm{a}}$ & $0.005 \pm 0.001^{\mathrm{c}}$ \\
\hline
\end{tabular}

$\mathrm{K}=$ Klebia; $\mathrm{T}=$ Tabarka; $\mathrm{H}=$ Haourea. For each report means that have values that are marked with more letters are significtly different at $\mathrm{P}<0.05$
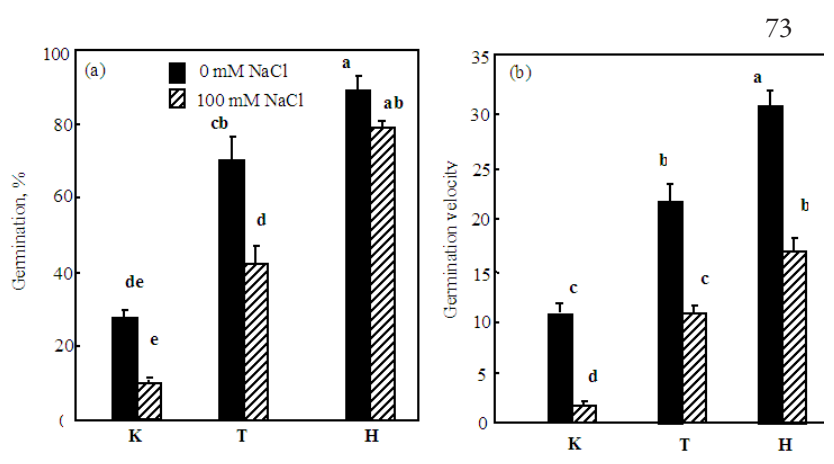

Fig. 1. Germination variability in three proveniences of $C$. maritimum; (a) final germination percentage; (b) germination velocity, $\mathrm{K}=$ Klebia provenience, $\mathrm{T}=$ Tabarka provenience, $\mathrm{H}=$ Haourea provenience. Mean values that are marked with more letters are significtly different at $\mathrm{P}<0.05$

mination percentage, the highest values being recorded in Haouaria, contrasting with Kelibia, whereas Tabarka displayed an intermediate behaviour (Fig. 1b). It is noteworthy that although salinity did not significantly affect the final germination percentage of Haouaria seeds, it significantly lowered the germination velocity (Fig. 1a and 1b). These findings are consistent with previous reports on halophytic species, such as A. halimus (Abbad et al., 2004) and in R. cruspus (Caver and Harper, 1967), which showed a variability in germination between different populations, whether collected from maritime littoral or from inland regions. A marked difference also characterised the seed germination pattern in the genus Agropyron: in the most tolerant species ( $A$. intermedium), it reached $74.6 \%$ at $1.8 \% \mathrm{NaCl}$, whereas germination was suppressed in the less tolerant (A.subsecundum) (Dewy, 1960).

The three proveniences were characterised by close values with respect to seed potassium content (Fig. 2a). In Tabarka and Haouaria spongy-coats, potassium concentrations were nearly twice higher than those found in seeds (Fig. 2a and 2b). In Kelibia, potassium content of the spongy-coat was similar to that of seeds. Sodium concentrations in the spongy-coat of the three proveniences were markedly higher, up to nine-fold than in seeds (Fig. $2 \mathrm{c}$ and $2 \mathrm{~d})$. In the same way, spongy-coat of the three proveniences contained up to 11 -fold more $\mathrm{Cl}^{-}$than seeds (Fig. $2 \mathrm{e}$ and $2 \mathrm{f}$ ). Significant variability was found in fruit and seed sodium contents, the highest values being observed in the less germinating accession Kelibia (Fig. $2 \mathrm{c}$ and $2 \mathrm{~d}$ ). This was also true for chloride content (Fig. $2 \mathrm{e}$ and $2 \mathrm{f}$ ). Hence, the mineral content analysis showed that $C$. maritimum L. allocated the toxic ions $\mathrm{Na}^{+}$and $\mathrm{Cl}^{-}$to the outer part of fruit (i.e. the spongy coat) (Fig. 2b, 2c and Tab. 1), likely to preserve the seed embryo from the toxic salt invasion over the maturation period. As suggested by the variability of seed germination, the successful achievement of this protective mechanism may influence the germination ability of this species in its natural biotopes.

Irrespective of the studied provenience, $\mathrm{K}^{+} / \mathrm{Na}^{+}$ratio was lower in the spongy-coats than in seeds (Tab. 2). In addition, the variability in $\mathrm{K}^{+} / \mathrm{Na}^{+}$ratio in both seeds and spongy-coats correlated to a certain extent with the vari- 
74

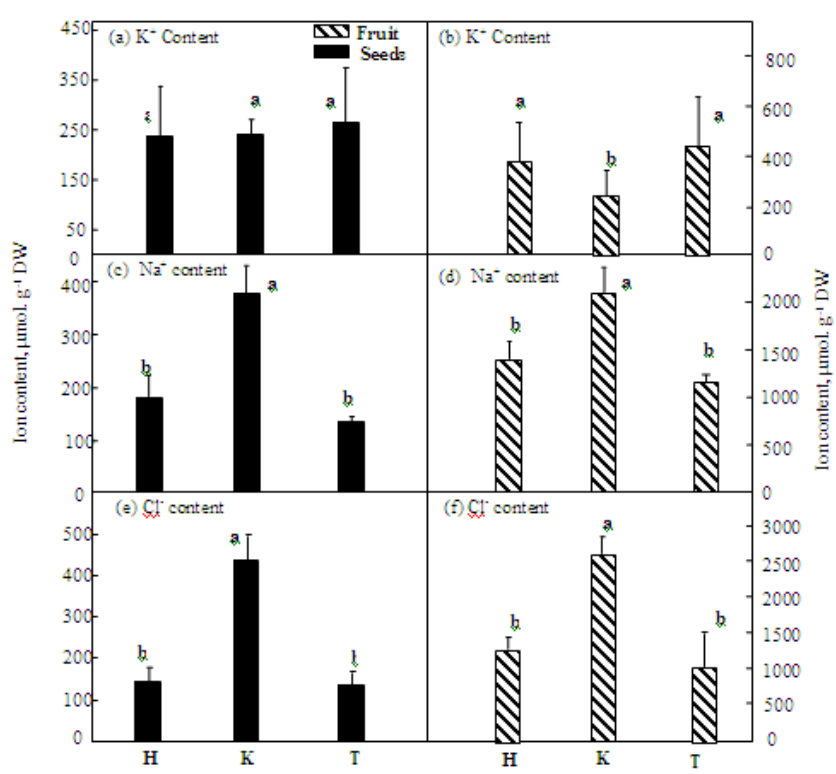

Fig. 2. Variability of $\mathrm{Na}^{+}, \mathrm{K}^{+}$, and $\mathrm{Cl}^{-}$content ( $\mu$ mol. $\mathrm{g}^{-1} \mathrm{DW}$ ) between provenience. $\mathrm{H}, \mathrm{K}$, and $\mathrm{T}$ stand for Haouaria, Kelibia, and Tabarka, respectively. Mean values that are marked with more letters are significtly different at $\mathrm{P}<0.05$

ability of the germination capacity. Indeed, Kelibia provenience presented the lowest $\mathrm{K}^{+} / \mathrm{Na}^{+}$values and showed the lowest germination capacity (Tab. 2, Fig. 1a and 1b), which could be explained by a lower efficiency to prevent the accumulation of $\mathrm{Na}^{+}$in the seed tissues. There is evidence that the increase of this ratio is associated with higher salt tolerance (Muhammed et al., 1987). Hence, the $\mathrm{K}^{+} / \mathrm{Na}^{+}$selectivity ratio could be a reliable indicator of the salt tolerance in C. maritimum $\mathrm{L}$. at the germination stage. Halophyte seeds respond to salt stress by entering in enforced dormancy (Khan and Ungar, 1997) but also by allocating the most toxic ions, in particular $\mathrm{Cl}^{-}$and $\mathrm{Na}^{+}$ in their external parts of their reproductive organs, as reported in S. physophora and H. ammodendron fruits (Song et al., 2005).

\section{Conclusions}

In conclusion, the fact that $C$. maritimum $\mathrm{L}$ seed germination capacity varied according to provenience indicates that environmental conditions, i.e. salt fluctuations, control germination capacity. Whether occurring in distilled water or at moderate salinity, germination was negatively affected by seed ion contents, suggesting that this process is strongly influenced by the salt accumulated in the soil, which is subsequently translocated towards fruits and seeds. Salt tolerance at the germination stage may be linked to the capacity of this species to limit salt accumulation to the peripheral parts of the fruit, owing to a selective absorption of potassium $v$ s. sodium.

\section{References}

Abbad, A., A. E. Hadrami and A. Benchaabane (2004). Germination response of the Mediterranean Saltbush
(Atriplex halimus L.) to $\mathrm{NaCl}$ Treatment. News paper of Agronomy 3:111-114.

Atia, A., K. Ben Hamed, A. Debez and C. Abdelly (2006). Salt and seawater effects on the germination of Crithmum maritimum, pp. 29-33. In: M. Öztürk, Y. Waisel, M. A. Khan, G. Görk, (Eds.). Biosaline Agriculture and Salinity Tolerance in Plants. Birkhäuser Verlag Switzerland.

Atia, A., A., Debez, Z. Barhoumi, A. Smaoui and C. Abdelly, (2009). ABA, GA3, and nitrate may control seed germination of Crithmum maritimum (Apiaceae) under saline conditions. Compte Rendus Biologie 332:704-710.

Bazzaz, F. A. (1973). Seed germination in relation to salt concentration in three populations of Prosopis farcta. Oecologia 13:73-80.

Debez, A., K. Ben Hamed, C. Grignon and C. Abdelly (2004). Salinity effects on germination, growth, and seed production of the halophyte Cakile maritima. Plant Soil 262:179-189.

Dewy, D. R. (1960). Salt tolerance of tewenty-five strains of Agropyron. Agronomy Journal 5:631-635.

Hosseini, M. K., A. A. Powell and I. J. Bingham (2002). Comparison of the seeds germination and early seedlings growth of soybean in saline conditions. Seed Science Research 12:165-172.

Khan, M. A. and I. A. Ungar (1997). Effect of light, salinity, and thermoperiod on the germination of halophytes. Canadian Journal of Botany 75:835-841.

Khan, M. A. and I. A. Ungar (1984). Effects of Salinity and temperature on the germination and growth Atriplex triangalus Wild. American Journal of Botany 7:481-489.

Meot-Duros, L. and C. Magné (2008). Effect of salinity and chemical factors on seed germination in the halophyte Crithmum maritimum L. Plant and Soil 313:83-87.

Muhammed, S., M. Akbar and H. U. Neue (1987). Effect of Na/ $\mathrm{Ca}$ and $\mathrm{Na} / \mathrm{K}$ ratios in saline culture solution on the growth and mineral nutrition in rice (Oryza sativa L.). Plant and Soil 104:57-62

Rehman, S., P. J. C. Harris, W. F. Bourne and J. Wilkin (2000). The relationship between ions, vigour and salinity tolerance of Acacia seeds. Plant and Soil 220:229-233.

Rehman, S., P. J. C. Harris, W. F. Bourne and J. Wilkin (1996). The effect of sodium chloride on germination and the potassium and calcium contents of Acacia seeds. Seed Science and Technology 25:45-57.

Song, J., G. Feng, C. Tian and F. Zhang (2005). Strategies for adaptation of Suaeda physophora, Haloxylon ammodondron and Haloxylon persicum to a saline environment during seedgermination stage. Annals of Botany 96:399-405.

Vicente, M. J., E. Conesa, A. Jose, J. lvarez-Rogel, J. A. Franco and J. J. Martinez-Sanchez (2007). Effects of various salts on the germination of three perennial salt marsh species. Aquatic Botany 87:167-170.

Zarrouk, M., H. El Almi, N. B. Youssef, N. Sleimi, D. B. Miled, A. Smaoui and C. Abdelly (2003). Lipid composition of local halophytes seeds: Cakile maritima, Zygophyllum album and Crithmum maritimum, pp.121-126. In: Lieth, H. and M. Mochtchenko (Eds.). Cash crop halophytes: Recent studies. Kluwer Academic Publishers, Dordrecht, Boston, London. 